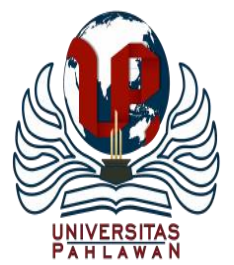

Edukatif : Jurnal Ilmu Pendidikan Volume 3 Nomor 4 Tahun 2021 Halm 1838 - 1848

EDUKATIF: JURNAL ILMU PENDIDIKAN

Research \& Learning in Education

https://edukatif.org/index.php/edukatif/index

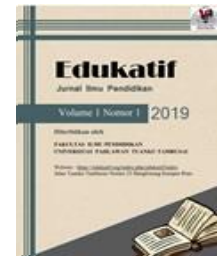

\title{
Pengaruh Self Efficacy Terhadap Minat Melanjutkan Studi S2 Pada Mahasiswa Prodi Pendidikan Administrasi Perkantoran
}

\author{
Lailatul Fitria Hanim $^{1 凶}$, Durinda Puspasari ${ }^{2}$ \\ Universitas Negeri Surabaya, Indonesia ${ }^{1,2}$ \\ E-mail : lailatul.17080314031@ mhs.unesa.ac.id ${ }^{1}$, durindapuspasari@unesa.ac.id ${ }^{2}$
}

\begin{abstract}
Abstrak
Tujuan penelitian ini adalah untuk menganalisis pengaruh self efficacy terhadap minat melanjutkan studi S2 pada mahasiswa Prodi Pendidikan Administrasi Perkantoran Universitas Negeri Surabaya. Penelitian ini merupakan penelitian kuantitatif. Teknik pengumpulan data yang digunakan adalah angket dan wawancara. Populasi dalam penelitian ini adalah mahasiswa program studi Pendidikan Administrasi Perkantoran Universitas Negeri Surabaya angkatan 2017 sebanyak 93 mahasiswa. Sampel dalam penelitian ini menggunakan non-probability sampling dengan bentuk sampling total, dimana jumlah sampel yang digunakan sama dengan jumlah populasi yaitu 93 mahasiswa. Uji coba instrumen dalam penelitian ini terdiri dari uji validitas dan uji reliabilitas. Teknik analisis data yang digunakan dalam penelitian ini yaitu: 1) uji asumsi klasik yang terdiri dari uji normalitas dan uji heteroskedastisitas; 2) uji hipotesis menggunakan regresi linier sederhana. Hasil penelitian menunjukkan bahwa terdapat pengaruh signifikan self efficacy terhadap minat melanjutkan studi S2 pada mahasiswa prodi Pendidikan Administrasi Perkantoran Universitas Negeri Surabaya.
\end{abstract}

Kata Kunci: Minat Melanjutkan Studi S2, Self Efficacy.

\begin{abstract}
This study aimed to analyze the effect of self-efficacy on the interest in continuing S2 studies in students of the Office Administration Education Study Program, State University of Surabaya. This research was quantitative. The data collection techniques used were questionnaires and interviews. The population in this study were students of the Office Administration Education study program, State University of Surabaya, class of 2017, as many as 93 students. The sample in this study used non-probability sampling with a total sampling form, where the number of pieces used was the same as the population, namely 93 students. Testing instruments in this study consisted of validity testing and reliability testing. The data analysis techniques used in this study were: 1) classical assumption test consisting of normality test and heteroscedasticity test; 2) hypothesis testing using simple linear regression. The results showed a significant effect of self-efficacy on the interest in continuing S2 studies in students of the Office Administration Education study program, State University of Surabaya.
\end{abstract}

Keywords: The Interest in Continuing S2 Studies; Self Efficacy.

Copyright (c) 2021 Lailatul Fitria Hanim, Durinda Puspasari

$\triangle$ Corresponding author

Email : lailatul.17080314031@mhs.unesa.ac.id

DOI : https://doi.org/10.31004/edukatif.v3i4.682

ISSN 2656-8063 (Media Cetak)

ISSN 2656-8071 (Media Online)

Edukatif : Jurnal Ilmu Pendidikan Vol 3 No 4 Tahun 2021 p-ISSN 2656-8063 e-ISSN 2656-8071 
1839 Pengaruh Self Efficacy terhadap Minat Melanjutkan Studi S2 pada Mahasiswa Prodi Pendidikan Administrasi Perkantoran- Lailatul Fitria Hanim, Durinda Puspasari

DOI : : https://doi.org/10.31004/edukatif.v3i4.682

\section{PENDAHULUAN}

Pendidikan merupakan hal yang sangat penting dalam kehidupan, pendidikan memberikan banyak manfaat bagi kehidupan salah satunya yaitu dapat menjadikan kehidupan tiap orang menjadi berdayaguna dan juga seringkali dibuat sebagai tolak ukur kesuksesan seseorang di masa depan. Semakin tinggi pendidikan yang dijalankan, maka semakin terbuka pula pikiran dan wawasan pengetahuannya. Menurut Undang-Undang Republik Indonesia Nomor 12 Tahun 2012 Tentang Pendidikan Tinggi, jenjang pendidikan setelah pendidikan menengah yang mencakup program diploma, program sarjana, program magister, program doktor, dan program profesi, serta program spesialis, yang diselenggarakan oleh perguruan tinggi berdasarkan kebudayaan bangsa Indonesia. Dengan pendidikan tinggi ini tiap orang dapat mengembangkan civitas akademikanya menjadi lebih inovatif, kreatif, dan berdaya saing. Pendidikan tinggi dibutuhkan untuk mengembangkan potensi tiap orang agar mampu menguasai cabang ilmu pengetahuan dan wawasan serta teknologi tertentu yang dapat bersaing di peradaban milenial ini. Selain itu, pendidikan tinggi membantu pemerintah dalam memetakan dan menyelaraskan kebutuhan dunia kerja dengan kompetensi yang diperoleh dari hasil pembelajaran di perguruan tinggi. Hal ini sesuai dengan pendapat Fatimatuzzahroh \& Puspasari, 2021) yang menyatakan bahwa the quality of human resources can be obtained from knowledge either from formal educational institutions such as schools, or from non-formal education such as courses and the surrounding environment. Dengan kata lain kualitas sumber daya manusia dapat diperoleh dari pengetahuan baik itu yang berasal dari pendidikan informal, pendidikan formal, maupun pendidikan nonformal.

Berdasarkan data pada laman website Bps.go.id (2020) menunjukkan catatan angka partisipasi sekolah berkisar umur 19-24 tahun wilayah provinsi Jawa Timur berisi mahasiswa S1-S2, dimana dari 3 tahun terakhir mengalami kenaikan, yakni pada tahun 2018 berjumlah 22,86; tahun 2019 berjumlah 24,80; dan tahun 2020 berjumlah 25,81 . Hal ini bisa dikatakan bahwa masih ada banyak mahasiswa lulusan sarjana yang lebih memilih untuk melanjutkan pendidikannya ke jenjang lebih tinggi seperti studi S2. Melanjutkan Studi S2 biasanya diawali dari minat mahasiswa untuk memperdalam dan mengembangkan ilmu pengetahuan serta untuk mendukung kenaikan jabatan yang biasanya diwajibkan untuk lulus S2. Djaali (2013) menyatakan bahwa minat pada dasarnya adalah penerimaan akan suatu hubungan antara diri sendiri dengan sesuatu di luar diri, semakin dekat hubungan tersebut semakin besar minatnya. Begitupun dengan Umma \& Margunani (2015) juga mengartikan minat sebagai keinginan, ketertarikan seseorang terhadap sesuatu atau hal. Minat merupakan suatu ketertarikan dari dalam diri seseorang terhadap sesuatu yang akan menimbulkan rasa senang ketika melakukannya tanpa ada yang mendorong untuk menyukai atau melakukan sesuatu tersebut (Mufida \& Effendi, 2019). Minat dapat muncul dengan sendirinya dan ada yang muncul karena dibangkitkan dengan usaha atau sengaja (Aziz, Akhyar, \& Suwachid, 2015). Jadi minat itu bisa berubah-ubah sesuai dengan hal-hal yang mempengaruhinya baik dari yang hanya terlihat saja maupun yang tiap harinya dikerjakan dalam kehidupan sehari-hari. Adanya minat untuk melanjutkan studi S2 akan mendorong mahasiswa untuk melakukan suatu tindakan dan partisipasi di dalamnya untuk memperoleh pengetahuan dan pengalaman baru di perguruan tinggi jenjang S2. Minat melanjutkan ke perguruan tinggi pada mahasiswa biasanya dipengaruhi oleh banyak hal, salah satunya yaitu self efficacy yang dimiliki tiap mahasiswa. Disamping minat, mahasiswa juga perlu didorong dengan adanya suatu kesadaran sendiri untuk disiplin belajar, jika tidak maka disiplin belajar tersebut tidak akan bertahan lama dalam diri mahasiswa tersebut. Sehingga pada saat melanjutkan studi S2 mahasiswa akan semakin termotivasi dalam belajar (Liubana \& Puspasari, 2021). Dalam melakukan suatu pembelajaran, mahasiswa perlu adanya suatu kesadaran sendiri untuk disiplin belajar. Disiplin belajar seorang mahasiswa dapat dibiasakan dan ditumbuhkan melalui penanaman suatu kebiasaan yang berhubungan dengan disiplin dimana bisa dimulai dari lingkungan keluarga.

King (2010) menyatakan bahwa self efficacy merupakan sebuah perasaan seseorang yang mampu mencapai tujuan-tujuan tertentu dan penguasaan untuk dapat memperoleh keterampilan dan mengatasi 
1840 Pengaruh Self Efficacy terhadap Minat Melanjutkan Studi S2 pada Mahasiswa Prodi Pendidikan Administrasi Perkantoran-Lailatul Fitria Hanim, Durinda Puspasari

DOI : : https://doi.org/10.31004/edukatif.v3i4.682

kendala-kendala dengan harapan untuk berhasil. Self efficacy sangat dibutuhkan seseorang untuk menjadi percaya pada apa yang seseorang bisa lakukan, dan bukan tentang apa yang harus dilakukan orang tersebut (Firmansyah, Komala, \& Rusdi, 2018). Efikasi diri menentukan bagaimana orang merasakan, berpikir, memotivasi diri sendiri dan bertingkah (Goulão, 2014). Baanu, Oyelekan, \& Olorundare (2016) juga menyatakan bahwa efikasi diri menentukan bagaimana orang merasa, berpikir, memotivasi diri sendiri, dan berperilaku. Iyoro, Shorunke, \& Akinola (2015) berpendapat bahwa self-efficacy menentukan bagaimana orang merasa, berpikir, memotivasi diri sendiri dan berperilaku, keyakinan semacam itu dihasilkan dapat mempengaruhi proses kerja secara tak terelakkan. Adanya self efficacy yang dimiliki tiap orang ini dapat membantu mereka dalam menyelesaikan berbagai hal, baik dari proses rencana pencapaian keinginan maupun penyelesaian berbagai masalah dalam kehidupan dengan mengandalkan kemampuan dan keyakinan dalam dirinya yang mampu membimbingnya menemukan berbagai cara untuk mencapai segala kepentingannya tersebut.

Ketika mahasiswa memiliki self efficacy yang tinggi maka akan semakin tinggi pula minatnya untuk melanjutkan pendidikan tinggi. Karena semakin tinggi keyakinan mahasiswa akan kemampuannya untuk menjalankan segala kegiatan ketika mengenyam pendidikan di perguruan tinggi jenjang S2, maka akan semakin tinggi minatnya untuk melanjutkan pendidikan ke perguruan tinggi jenjang S2 tersebut. Begitupun sebaliknya, semakin rendah self efficacy yang dimiliki maka akan semakin rendah pula minat melanjutkan pendidikan ke perguruan tinggi jenjang S2. Hal ini disebakan oleh rasa tidak percaya diri mahasiswa yang menganggap semakin tinggi pendidikan maka akan semakin sulit pelajaran yang diberikan. Hal ini berkaca pada pengalaman masing-masing mahasiswa yang saat ini masih mengenyam pendidikan jenjang S1 di semester akhir.

Penelitian ini didukung oleh penelitian sebelumnya yang dilakukan oleh Haq \& Setiyani (2016) yang menyatakan bahwa ada pengaruh yang positif dan signifikan antara self efficacy terhadap minat melanjutkan studi ke perguruan tinggi. Sasmito, Wahyuni, \& Zulianto (2021) dalam penelitiannya yang menjelaskan efikasi diri memiliki pengaruh yang signifikan terhadap minat berwirausaha siswa kelas XII Jurusan Pemasaran SMKN 1 Jember. Begitu juga dengan hasil penelitian Subarkah \& Nurkhin (2018) menunjukkan bahwa ada pengaruh yang positif dan signifikan efikasi diri terhadap minat melanjutkan ke perguruan tinggi pada siswa kelas XII XMA Negeri 1 Kejobong tahun pelajaran 2017/2018.

Berdasarkan hasil wawancara yang peneliti lakukan dengan beberapa mahasiswa prodi Pendidikan Administrasi Perkantoran angkatan 2017 di Fakultas Ekonomika dan Bisnis Universitas Negeri Surabaya yang saat ini sedang melaksanakan skripsi menyatakan bahwa beberapa mahasiswa memiliki minat melanjutkan studi S2 dan beberapa mahasiswa lainnya tidak karena lebih memilih untuk fokus bekerja. Hal ini berkaitan erat dengan salah satu indikator self efficacy yang diukur dari tiga dimensi yang dikemukakan oleh Zimmerman (2000) yakni strength, yang mana mahasiswa dengan kepercayaan diri yang kuat akan kemampuannya lebih memiliki ketahanan diri untuk tidak menyerah dalam mencapai tujuan yang diinginkan seperti tidak menyerah dalam mencapai minatnya melanjutkan studi S2. Begitupun sebaliknya, mahasiswa dengan kepercayaan diri lemah pada kemampuannya senantiasa merasa mudah putus asa dengan usahausahanya sehingga lebih memilih fokus bekerja untuk mendapatkan penghasilan yang baik. Sehingga minatnya untuk melanjutkan studi S2 pun rendah.

Mahasiswa yang berminat melanjutkan studi S2 kebanyakan adalah mahasiswa dengan rasa percaya tinggi, sedangkan mahasiswa yang tidak memiliki minat melanjutkan studi S2 adalah mahasiswa dengan rasa percaya diri rendah. Mereka merasa tidak mampu untuk melanjutkan studi S2 dan tidak mampu menjalankan tugas akhir yang ada di jenjang S2. Adapun tujuan penelitian ini adalah untuk menganalisis pengaruh self efficacy terhadap minat melanjutkan studi S2 pada mahasiswa Prodi Pendidikan Administrasi Perkantoran Universitas Negeri Surabaya. Adapun perbedaan penelitian ini dengan penelitian terdahulu yakni terletak pada respondennya, Dimana penelitian terdahulu respondennya adalah siswa SMA/SMK sedangkan penelitian ini 
1841 Pengaruh Self Efficacy terhadap Minat Melanjutkan Studi S2 pada Mahasiswa Prodi Pendidikan Administrasi Perkantoran- Lailatul Fitria Hanim, Durinda Puspasari

DOI : : https://doi.org/10.31004/edukatif.v3i4.682

adalah mahasiswa semester akhir yang sedang dalam proses penentuan kelanjutan karirnya dimana harus melanjutkan studi S2 atau langsung bekerja.

\section{METODE PENELITIAN}

Penelitian ini merupakan penelitian kuantitatif. Penelitian kuantitatif merupakan penelitian yang berlandaskan pada filsafat positivisme untuk meneliti populasi atau sampel tertentu dan pengambilan sampel secara random dengan pengumpulan data menggunakan instrumen, analisis data bersifat statistic (Sugiyono, 2019). Populasi dalam penelitian ini adalah mahasiswa prodi Pendidikan Administrasi Perkantoran angkatan 2017 yang berjumlah 93 mahasiswa. Pengambilan sampel dilakukan dengan menggunakan teknik nonprobability sampling bentuk sampling total. Sampling total adalah teknik pengambilan sampel dimana seluruh anggota populasi dijadikan sampel semua (Sugiyono, 2019). Sehingga jumlah sampel dalam penelitian ini adalah sama dengan jumlah populasi yaitu 93 mahasiswa. Teknik pengumpulan data yang digunakan adalah angket dengan menggunakan skala likert dan wawancara untuk studi pendahuluan dengan menggunakan pedoman wawancara tidak terstruktur. Model konseptual penelitian ini dapat dilihat pada gambar 1 sebagai berikut:

\section{Gambar 1. Model Konseptual Penelitian}

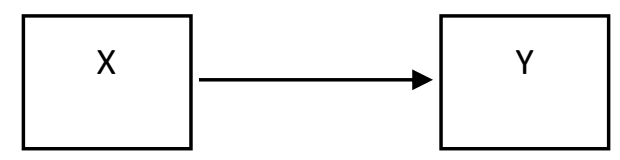

Keterangan:

X : Self Efficacy

Y : Minat Melanjutkan Studi S2

: Pengaruh X terhadap Y

Hipotesis pada penelitian ini sebagai berikut:

$\mathrm{H}_{\mathrm{a}} \quad$ : Terdapat pengaruh signifikan self efficacy terhadap minat melanjutkan studi S2 pada mahasiswa prodi Pendidikan Administrasi Perkantoran Universitas Negeri Surabaya

$\mathrm{H}_{0} \quad$ : Tidak terdapat pengaruh signifikan self efficacy terhadap minat melanjutkan studi S2 pada mahasiswa prodi Pendidikan Administrasi Perkantoran Universitas Negeri Surabaya

Uji coba instrumen data dan analisis data menggunakan SPSS 21, dikarenakan lebih mudah penggunaannya dan variabel dependen dalam penelitian ini tidak lebih dari satu. Sehingga lebih cocok menggunakan program SPSS 21 untuk mengolah datanya. Uji coba instrumen yang digunakan dalam penelitian ini terdiri dari: 1) uji validitas, validitas berkenaan dengan ketepatan alat ukur terhadap konsep yang diukur, sehingga benar-benar mengukur apa yang seharusnya diukur. Instrumen dikatakan valid, jika nilai $r$ hitung > $\mathrm{r}$ tabel (Nurhasanah, 2017); 2) uji reliabilitas, yaitu untuk mengukur suatu kuesioner. Uji reliabilitas ini menggunakan cronbach alpha. Jika nilai cronbach alpha $>0,60$ maka kuesioner atau angket dinyatakan reliabel (Sujarweni, 2014).

Teknik analisis data yang digunakan dalam penelitian ini terdiri dari: 1) Uji Asumsi Klasik yang meliputi a) Uji Normalitas, untuk menguji data variabel bebas (X) dan data variabel terikat (Y) pada persamaan regresi yang dihasilkan, apakah berdistribusi normal atau berdistribusi tidak normal (Sunyoto, 2013). Uji normalitas ini menggunakan uji kolmogorov-smirnov, dimana dalam uji kolmogorov-smirnov, data dikatakan berdistribusi normal jika nilai sig > 0,05; b) Uji Heteroskedastisitas, bertujuan untuk menguji apakah dalam model regresi terjadi ketidaksamaan varians dari residual satu pengamatan ke pengamatan yang 
1842 Pengaruh Self Efficacy terhadap Minat Melanjutkan Studi S2 pada Mahasiswa Prodi Pendidikan Administrasi Perkantoran- Lailatul Fitria Hanim, Durinda Puspasari

DOI : : https://doi.org/10.31004/edukatif.v3i4.682

lain (Ghozali, 2018). Uji heteroskedastisitas ini menggunakan scatterplot. Dikatakan tidak terjadi heteroskedastisitas apabila tidak ada pola yang jelas, serta titik-titik menyebar di atas dan di bawah angka 0 pada sumbu Y; 2) Uji hipotesis menggunakan Regresi Linier Sederhana yang bertujuan untuk menganalisis apakah terdapat pengaruh self efficacy (X) terhadap minat melanjutkan studi S2 pada mahasiswa prodi Pendidikan Administrasi Perkantoran Universitas Negeri Surabaya (Y).

\section{HASIL DAN PEMBAHASAN PENELITIAN}

Hasil uji coba instrumen dalam penelitian ini dapat dijelaskan sebagai berikut:

Berdasarkan pengolahan data melalui program aplikasi SPSS 21 dapat dinyatakan bahwa 48 item pernyataan yang telah diujikan dan diolah uji validitasnya dinyatakan valid. Data dinyatakan valid karena nilai $r$ hitung lebih besar daripada $r$ tabel.

Berdasarkan tabel reliability statistics menunjukkan bahwa nilai Cronbach's Alpha variabel Self Efficacy (X) sebesar 0,934 > 0,60 dan variabel Minat Melanjutkan Studi S2 (Y) sebesar 0,921 > 0,60 maka artinya data tersebut dinyatakan reliabel.

Hasil uji asumsi klasik pada penelitian ini dapat dipaparkan sebagai berikut:

Tabel 1

One-Sample Kolmogorov-Smirnov Test

\begin{tabular}{lll}
\hline & & $\begin{array}{l}\text { Unstandardized } \\
\text { Residual }\end{array}$ \\
\hline $\mathrm{N}$ & & 93 \\
\hline \multirow{2}{*}{ Normal Parameters } & & .0000000 \\
& Mean & 13.01344615 \\
& Std. Deviation & .079 \\
\cline { 2 - 3 } Most Extreme Differences & Absolute & .054 \\
\cline { 2 - 3 } & Positive & -.079 \\
\hline Kolmogorov-Smirnov Z & Negative & .766 \\
\hline Asymp. Sig. (2-tailed) & & .601 \\
\hline a. Test distribution is Normal. & & \\
b. Calculated from data. & &
\end{tabular}

Berdasarkan tabel 1 One-Sample Kolmograv-Smirnov Test di atas, diketahui bahwa nilai Asymp. Sig. (2-tailed) sebesar 0,601>0,05. Maka dapat disimpulkan bahwa data berdistribusi normal.



Gambar 2. Hasil Uji Heteroskedastisitas 
Berdasarkan uji heteroskedastisitas dengan melihat gambar scatterplot, diketahui bahwa titik-titik data menyebar di atas dan di bawah atau sekitar 0 dan penyebaran titik-titik data tidak membentuk suatu pola, sehingga dapat disimpulkan bahwa data tidak terjadi heteroskedastisitas.

Uji hipotesis pada penelitian ini menggunakan uji regresi linier sederhana. Karena untuk memprediksi dan menguji pengaruh satu variabel independen terhadap variabel dependen yakni pengaruh self efficacy terhadap minat melanjutkan studi S2. Jika variabel independen (self efficacy) diketahui nilainya, maka variabel dependen (minat melanjutkan studi S2) dapat diprediksi besarnya. Hasil uji regresi linier sederhana dapat dilihat sebagai berikut:

Tabel 2

Coefficients $^{\mathrm{a}}$

\begin{tabular}{lllllll}
\hline \multirow{2}{*}{ Model } & \multicolumn{2}{c}{ Unstandardized Coefficients } & $\begin{array}{l}\text { Standardized } \\
\text { Coefficients }\end{array}$ & t & Sig. \\
\cline { 3 - 5 } & & \multicolumn{2}{c}{ B } & Std. Error & Beta & \\
\hline \multirow{2}{*}{1} & (Constant) & 39.450 & 14.414 & & 2.737 & .007 \\
& Self Efficacy & .282 & .119 & .241 & 2.372 & .020 \\
\hline
\end{tabular}

a. Dependent Variable: Minat Melanjutkan Studi S2

Berdasarkan tabel 2 di atas dapat diketahui model persamaan regresi linier sederhana sebagai berikut: Y $=39,450+0,282 \mathrm{X}$

Dimana $\mathrm{Y}$ adalah minat melanjutkan studi S2 dan X adalah self efficacy. Persamaan regresi linier sederhana tersebut mempunyai makna sebagai berikut:

1. Konstanta $=39,450$

Artinya apabila variabel independen yaitu self efficacy $(\mathrm{X})$ bernilai 0 , maka variabel dependen yaitu minat melanjutkan studi S2 $(\mathrm{Y})=39,450$.

2. Koefisien X (self efficacy) $=0,282$

Artinya setiap variabel self efficacy mengalami kenaikan sebesar satu satuan, maka akan menyebabkan peningkatan terhadap minat melanjutkan studi S2 sebesar 0,282 satuan.

Hasil uji regresi linier sederhana dapat dilihat pada self efficacy $(\mathrm{X})$ berpengaruh signifikan terhadap minat melanjutkan studi S2 pada mahasiswa prodi Pendidikan Administrasi Perkantoran Universitas Negeri Surabaya dengan nilai sig. $0,020<0,05$ dan $\mathrm{t}_{\text {hitung }} 2,372>\mathrm{t}_{\text {tabel }} 2,013$ yang artinya $\mathrm{H}_{\mathrm{a}}$ diterima.

Tabel 3

Model Summary ${ }^{\mathrm{b}}$

\begin{tabular}{|c|c|c|c|c|}
\hline Model & $\mathrm{R}$ & R Square & Adjusted R Square & $\begin{array}{l}\text { Std. Error of the } \\
\text { Estimate }\end{array}$ \\
\hline 1 & $.241^{\mathrm{a}}$ & .058 & .048 & 13.085 \\
\hline
\end{tabular}

Berdasarkan tabel 3 model summary, diketahui bahwa koefisien determinasi ( $R$ Square) sebesar 0,058. Artinya variabel self efficacy $(\mathrm{X})$ memiliki kontribusi atau dengan kata lain pengaruh terhadap variabel minat 
1844 Pengaruh Self Efficacy terhadap Minat Melanjutkan Studi S2 pada Mahasiswa Prodi Pendidikan Administrasi Perkantoran- Lailatul Fitria Hanim, Durinda Puspasari

DOI : : https://doi.org/10.31004/edukatif.v3i4.682

melanjutkan studi S2 (Y) sebesar 5,8\% sedangkan sisanya dipengaruhi oleh variabel lain yang tidak diteliti dalam penelitian ini.

\section{Pengaruh Self Efficacy terhadap Minat Melanjutkan Studi S2 pada Mahasiswa Prodi Pendidikan Administrasi Perkantoran Universitas Negeri Surabaya}

Berdasarkan hasil uji-t diketahui nilai sig. sebesar $0,020<0,05$ dan $t_{\text {hitung }} 2,372>t_{\text {tabel }} 2,013$ yang menunjukkan bahwa $\mathrm{H}_{a}$ diterima, hal ini berarti terdapat pengaruh signifikan self efficacy terhadap minat melanjutkan studi S2 pada mahasiswa prodi Pendidikan Administrasi Perkantoran Universitas Negeri Surabaya. Penelitian ini sejalan dengan penelitian Prianggita \& Ghofur (2021) yang menunjukkan bahwa self efficacy berpengaruh positif terhadap minat melanjutkan pendidikan ke perguruan tinggi. Seseorang yang memiliki self efficacy tinggi percaya jika dirinya mampu untuk melaksanakan aktivitas yang akan dilakukannya. Penelitian Sofiyanti \& Sukirman (2019) juga menyebutkan bahwa efikasi diri mempunyai pengaruh positif dan signifikan terhadap minat melanjutkan pendidikan ke perguruan tinggi. Kalau tingkat self efficacy siswa makin tinggi, maka minat untuk melanjutkan pendidikan juga makin tinggi dan begitu sebaliknya. Namun, keyakinan pada diri siswa bisa melemah ketika memperoleh kendala yang dirasa sulit, sehingga mereka ragu untuk merealisasikan minatnya melanjutkan pendidikan. Penelitian Kustiani, Sugiharto, \& Anni (2019) menyebutkan bahwa terdapat pengaruh yang signifikan antara self-efficacy dengan minat studi lanjut ke perguruan tinggi siswa kelas XI SMA Negeri 1 Mayong. Self efficacy atau keyakinan diri akan menumbuhkan rasa optimisme, percaya diri, dan mindset yang positif tentang kesulitan yang harus dihadapi dan diselesaikan. Self efficacy yang tinggi akan dengan mudah meningkatkan kemampuan seseorang dan menentukan keputusan tentang upaya untuk memperoleh apa yang diinginkan. Hasil penelitian Birama \& Nurkhin (2017) juga mengungkapkan bahwa efikasi diri berpengaruh secara positif dan signifikan terhadap melanjutkan pendidikan ke perguruan tinggi. Siswa dengan efikasi diri tinggi akan lebih berani untuk mengambil resiko dalam setiap upaya yang dijalankannya untuk mewujudkan minatnya melanjutkan pendidikan. Begitu juga dengan penelitian Lase, Idris, \& Azhar (2018) yang menyebutkan bahwa self efficacy berpengaruh positif dan signifikan terhadap minat melanjutkan kuliah siswa. Semakin baik efikasi diri, semakin baik pula minat untuk melanjutkan pendidikan. Penelitian ini sesuai dengan penelitian terdahulu dan belum ada yang bertentangan mengenai penelitian tersebut.

Adanya hasil penelitian tersebut sejalan dengan kondisi fakta di lapangan yang diperoleh melalui penyebaran angket yang menunjukkan bahwa mahasiswa dengan self efficacy tinggi cenderung melakukan pengaturan diri dalam menyelesaikan tugas akademik dengan derajat kesulitan yang berbeda-beda, membuat perencanaan penyelesaian tugas dengan mengacu pada kemampunnya dalam menjadikan pengalaman sebelumnya sebagai kekuatan dalam mencapai hasil belajar yang optimal serta menguatkan keyakinannya untuk bertahan dalam usaha-usaha yang telah dilakukannya untuk mencapai tujuan yang diinginkan. Mahasiswa yang memiliki kepercayaan tinggi tersebut merasa mampu untuk melanjutkan studi S2. Sehingga mereka melakukan berbagai usaha seperti mencari informasi mengenai studi S2 bahkan ikut terlibat dalam kegiatan di dalamnya demi mencapai minatnya itu. Adanya pengaruh self efficacy terhadap minat melanjutkan studi S2 ini ditunjang oleh dukungan sosial dari orang-orang sekitar, yang mana kepercayaan diri akan lebih meningkat lagi ketika mendapat dukungan yang positif dari orang-orang sekitar yang mendukung mahasiswa untuk melanjutkan studi S2.

Hasil penelitian yang telah dilaksanakan menunjukkan bahwa self efficacy yang dimiliki oleh mahasiswa menjadi salah satu pendorong mahasiswa untuk memiliki minat melanjutkan studi S2. Minat muncul dapat dilihat dari sikap seseorang yang mulai menaruh perhatian pada suatu hal yang menjadi keinginan dan kegemarannya (Nurjannah \& Kusmuriyanto, 2016). Jadi apabila mahasiswa menginginkan dan menggemari sesuatu hal, maka bisa dikatakan mereka memang tertarik dengan hal tersebut. Minat dapat berkembang apabila seseorang memiliki perhatian yang khusus terhadap hal yang diminatinya, dengan kata 
1845 Pengaruh Self Efficacy terhadap Minat Melanjutkan Studi S2 pada Mahasiswa Prodi Pendidikan Administrasi Perkantoran- Lailatul Fitria Hanim, Durinda Puspasari

DOI : : https://doi.org/10.31004/edukatif.v3i4.682

lain minat menjadi lebih meningkat ketika mahasiswa memberikan perhatiannya pada minatnya tersebut (Setiaji \& Rachmawati, 2017). Semakin tinggi minat yang dimiliki mahasiswa maka akan semakin banyak pula cara yang akan ditempuh untuk mencapai keinginannya tersebut melalui aktivitas-aktivitas tertentu yang mendukung pencapaian keinginannya itu. Dalam mencapai minatnya tersebut, mahasiswa tidak terlepas dari self efficacy yang mereka miliki. Blotnicky, et al (2018) menyatakan efikasi diri mengacu pada keyakinan bahwa seseorang memiliki kemampuan sendiri untuk melakukan dengan sukses perilaku tertentu berdasarkan persepsi mereka tentang kemampuan mereka dan kemungkinan pencapaian kesuksesan mereka dalam aktivitas itu. Mahasiswa dengan self efficacy yang dimiliki bisa melakukan berbagai usaha untuk mencapai tujuannya sesuai dengan kemampuan yang dimiliki. Begitupun juga dengan Falconer \& Djokic (2019) yang berpendapat bahwa self-efficacy mengacu pada penilaian seseorang tentang kemampuan mereka untuk melakukan tugas tertentu. Dengan penilaian tersebut mahasiswa bisa mengetahui apa yang kurang dari kemampuan yang mereka milliki guna mencapai tujuan yang diinginkan.

Self efficacy masing-masing mahasiswa dalam mencapai tujuan yang diinginkan tidaklah sama, ada yang merasa kemampuannya rendah dan ada yang merasa kemampuannya tinggi. Self efficacy yang rendah akan mempengaruhi minat mahasiswa untuk melanjutkan studi S2. Karena mereka merasa kurang mampu dalam menyelesaikan tugas maupun pembelajaran yang diberikan di studi S2 nya nanti. Seseorang dengan self-efficacy rendah menganggap dirinya pada dasarnya tidak mampu melakukan segalanya (Widyani, Sarmawa, \& Dewi, 2017). Individu dengan efikasi diri rendah cenderung menghindari hal-hal yang sulit (Sudjarwo, Wahyudin, \& Sudarma, 2019). Sikap tidak percaya diri, mudah menyerah dan mudah putus serta cenderung menghindari hal-hal sulit itulah yang bisa membuat minat mahasiswa untuk melanjutkan studi S2 menjadi rendah. Self efficacy yang tinggi akan memberi peluang besar bagi mahasiswa untuk mencapai tujuan dan keinginannya. Dengan memiliki self efficacy yang tinggi, mahasiswa akan selalu berusaha untuk bertahan demi mencapai keinginannya tersebut untuk melanjutkan studi S2.

Self efficacy yang dimiliki mahasiswa akan membantunya untuk menetapkan perencanaan serta pengaturan diri dalam penyelesaian berbagai tugas akademik, membantu dalam mengasah kemampuannya untuk menjadikan pengalaman sebelumnya sebagai kekuatan dalam mencapai hasil belajar yang optimal, serta membantu dalam mempertahankan usaha-usaha yang dilakukannya untuk mencapai tujuan belajar yang diharapkan. Ahmad \& Safaria (2013) menyatakan pula bahwa tingkat efikasi diri yang tinggi menuntun orang untuk bekerja keras dan bertahan dalam menghadapi kemunduran. Tinggi rendahnya self efficacy mahasiswa menentukan cara-cara yang mereka gunakan untuk mencapai minatnya tersebut. Dengan mempertimbangkan kemampuan yang dimiliki setiap mahasiswa bisa menjadi acuan untuk melanjutkan studi S2. Sehingga bisa meningkatkan self efficacy mahasiswa agar mereka mampu menghadapi segala hal dan situasi yang akan dihadapi dalam melanjutkan studi S2 nanti dan minat mereka untuk melanjutkan studi S2 menjadi semakin besar.

Keterbatasan penelitian ini adalah hanya berfokus pada pengaruh self efficacy terhadap minat melanjutkan studi S2. Adapun penelitian ini dikhususkan untuk mengetahui minat melanjutkan studi S2 mahasiswa prodi pendidikan administrasi perkantoran angkatan 2017 melalui self efficacy yang dimiliki tiap mahasiswa.

\section{KESIMPULAN}

Berdasarkan hasil penelitian, dapat disimpulkan bahwa: (1) self efficacy berpengaruh positif dan signifikan terhadap minat melanjutkan studi S2 pada mahasiswa prodi Pendidikan Administrasi Perkantoran Universitas Negeri Surabaya dengan nilai sig. 0,020<0,05 dan $t_{\text {hitung }} 2,372>t_{\text {tabel }} 2,013$ yang artinya $H_{a}$ diterima. Semakin meningkatnya self efficacy mahasiswa maka semakin meningkat pula minatnya untuk melanjutkan studi S2. Hal ini sesuai fakta di lapangan yang menunjukkan bahwa mahasiswa prodi Pendidikan 
1846 Pengaruh Self Efficacy terhadap Minat Melanjutkan Studi S2 pada Mahasiswa Prodi Pendidikan Administrasi Perkantoran-Lailatul Fitria Hanim, Durinda Puspasari

DOI : https://doi.org/10.31004/edukatif.v3i4.682

Administrasi Perkantoran memiliki self efficacy yang tinggi sehingga minatnya untuk melanjutkan studi S2 juga tinggi. (2) variabel self efficacy memiliki kontribusi terhadap variabel minat melanjutkan studi S2 sebesar 5,8\% sedangkan sisanya dipengaruhi oleh variabel lain yang tidak diteliti dalam penelitian ini.

\section{DAFTAR PUSTAKA}

Ahmad, A. \& Safaria, T. (2013). Effects of Self-Efficacy on Students' Academic Performance. Journal of Educational, Health and Community Psychology, 2(1), 22-29. https://doi.org/10.12928/jehcp.v2i1.3740.

Aziz, A., Akhyar, M., \& Suwachid. (2015). Hubungan Prestasi Belajar dan Kondisi Ekonomi Keluarga dengan Minat Melanjutkan Studi S2 Mahasiswa Program Studi Pendidikan Teknik Mesin FKIP UNS Semester VIII Tahun Akademik 2012/2013. Jiurnal Nosel, 4(1), 1-7. https://jurnal.fkip.uns.ac.id/index.php/ptm/article/view/8089/5855.

Baanu, T. F., Oyelekan, O. S., \& Olorundare, A. S. (2016). Self-Efficacy and Chemistry Students' Academic Achievement in Senior Secondary Schools in North-Central ,Nigeria. The Malaysian Online Journal of Educational Science, 4(1), 43-52. https://eric.ed.gov/?id=EJ1095991.

Birama, B. C. \& Nurkhin, A. (2017). Peran Efikasi Diri dalam Memediasi Pengaruh Perencanaan Karier dan Lingkungan Teman Sebaya terhadap Minat Melanjutkan Pendidikan ke Perguruan Tinggi Siswa SMA Negeri 2 Slawi. Economic Education Analysis Journal, 6(1), 109-119. http://journal.unnes.ac.id/sju/index.php/eeaj/article/view/13477.

Blotnicky, K. A., et al. (2018). A Study of the Correlation Between STEM Career Knowledge, Mathematics Self- Efficacy, Career Interests, and Career Activities on the Likelihood of Pursuing a STEM Career among Middle School Students. International Journal of STEM Education, 5(22), 1-15. https://link.springer.com/content/pdf/10.1186/s40594-018-0118-3.pdf.

Bps.go.id. (2020). Indikator Pendidikan, 1994-2020. https://www.bps.go.id/staticable/2010/03/19/1525/indikator-pendidikan-1994-2020.html, diakses pada 20 Januari 2021.

Djaali. (2013). Psikologi Pendidikan. Jakarta: PT Bumi Aksara.

Falconer, A. \& Djokic, B. (2019). Factors Affecting Academic Self-Efficacy and Academic SelfHandicapping Behaviors in Doctoral Students. Internatioanl Journal of Doctoral Studies, 14, 637-649. https://doi.org/https://doi.org/10.28945/4414.

Fatimatuzzahroh, S. \& Puspasari, D. (2021). the Influence of Using Typing Master Application Media on 10 Finger Typing Skills in Office Technology Subjects at SMK Muhammadiyah 2 Sumberrejo Bojonegoro. Jurnal Mantik, 5(1), 1-6. https://iocscience.org/ejournal/index.php/mantik/article/view/1249.

Firmansyah, F., Komala, R., \& Rusdi. (2018). Self Efficacy and Motivation: Improving Biology Learning Outcomes of Senior High School Students. Indonesian Journal of Biology Education, 4(3), 203-208. http://ejournal.umm.ac.id/index.php/jpbi/article/view/6878/6058.

Ghozali, I. (2018). Aplikasi Analisis Multivariete SPSS 25 (9th ed.). Semarang: Universitas Diponegoro.

Goulão, M. de F. (2014). The Relationship Between Self-Efficacy and Academic Achievement in Adults' Learners. Athens Journal of Education, 1(3), 237-246. https://eric.ed.gov/?id=EJ1217649.

Haq, A. \& Setiyani, R. (2016). Pengaruh Prestasi Belajar, Kondisi Sosial Ekonomi Orang Tua dan Self Efficacy terhadap Minat Melanjutkan Studi ke Perguruan Tinggi Siswa IPS. Economic Education Analysis Journal, $\quad$ 5(3), 1034-1045. https://journal.unnes.ac.id/sju/index.php/eeaj/article/view/13603/7465.

Iyoro, Shorunke, \& Akinola. (2015). Demographic Variables, Self-Efficacy and Work-Family Conflict among Women Librarians in Ondo State Nigeria. Journal of Library \& Information Science, 5(1), 148-161. http://irjlis.com/wp-content/uploads/2015/06/10-IR-267.pdf.

King, L. A. (2010). Psikologi Umum: Sebuah Pandangan Apresiatif. Jakarta: Salemba Humanika. 
1847 Pengaruh Self Efficacy terhadap Minat Melanjutkan Studi S2 pada Mahasiswa Prodi Pendidikan Administrasi Perkantoran-Lailatul Fitria Hanim, Durinda Puspasari

DOI : https://doi.org/10.31004/edukatif.v3i4.682

Kustiani, K. P., Sugiharto, D. Y. P., \& Anni, C. T. (2019). Minat Studi Lanjut ke Perguruan Tinggi Siswa Ditinjau dari Self-Efficacy dan Aspirasi Orang Tua. Psychocentrum Review, 1(1), 17-26. https://doi.org/https://doi.org/10.30998/pcr.115.

Lase, I. P. S., Idris, \& Azhar, Z. (2018). Factors Influencing Vocational Students Interest in Nias District in Continuing Studies Into Universities. International Journal of Progressive Sciences and Technologies, 10(1), 201-208. http://www.ijpsat.es/index.php/ijpsat/article/view/513/319.

Liubana, A. \& Puspasari, D. (2021). Analisis Pengaruh Penggunaan E-Learning dengan Google Classroom dan Disiplin Belajar terhadap Motivasi Belajar Mahasiswa Brothers and Sisters House Kota Surabaya pada Masa Pandemi Covid-19. Jurnal Kependidikan: Jurnal Hasil Penelitian dan Kajian Kepustakaan di Bidang Pendidikan, Pengajaran dan Pembelajaran, 7(2), 417-427. https://ejournal.undikma.ac.id/index.php/jurnalkependidikan/article/view/3599.

Mufida, A. \& Effendi, Z. M. (2019). Pengaruh Pendapatan Orang Tua dan Prestasi Belajar terhadap Minat Melanjutkan Pendidikan ke Perguruan Tinggi pada Siswa Kelas XII Akuntansi SMK Negeri 2 Pariaman. Jurnal Ecogen, 2(4), 687-695. http://ejournal.unp.ac.id/students/index.php/pek/article/view/7846/3635.

Nurhasanah, S. (2017). Praktikum Statistika 2 untuk Ekonomi dan Bisnis. Jakarta: Salemba Empat.

Nurjannah, L. A. \& Kusmuriyanto. (2016). Pengaruh Prestasi Belajar, Motivasi Belajar, Kondisi Sosial Ekonomi Orang Tua dan Lingkungan Sosial terhadap Minat Melanjutkan ke Perguruan Tinggi. $\begin{array}{llll}\text { Economic Education Analysis } & \text { 40urnal, }\end{array}$ https://journal.unnes.ac.id/sju/index.php/eeaj/article/view/13584.

Prianggita, M. \& Ghofur, M. A. (2021). Analisis Variabel-variabel yang Mempengaruhi Minat Siswa SMA Melanjutkan Pendidikan ke Perguruan tinggi. Edunomic: Jurnal Ilmiah Pendidikan Ekonomi Fakultas Keguruan dan Ilmu Pendidikan, 9(1), 26-36. https://doi.org/10.33603/ejpe.v9i1.3519.

Sasmito, H., Wahyuni, S., \& Zulianto, M. (2021). Pengaruh Kecerdasan Adversitas dan Efikasi Diri terhadap Minat Berwirausaha Siswa Kelas XII Pemasaran SMK Negeri 1 Jember. Jurnal Ilmiah Ilmu Pendidikan, Ilmu Ekonomi, dan Ilmu Sosial, 15(1), 130-135. https://doi.org/10.19184/jpe.v15i1.20654.

Setiaji, K. \& Rachmawati, D. (2017). Minat Melanjutkan Studi Perguruan Tinggi Siswa SMKN Kota $\begin{array}{lllll}\text { Semarang. } & \text { Jurnal } & \text { Pendidikan } & \text { Ekonomi, } & 10(1),\end{array}$ https://doi.org/https://dx.doi.org/10.17977/UM014v10i12017p045.

Sofiyanti, U. \& Sukirman. (2019). Minat Melanjutkan Pendidikan ke Perguruan Tinggi: Studi Empiris tentang Pengaruh Mediasi Prestasi Belajar. Economic Education Analysis Journal, 8(2), 453-469. https://doi.org/10.15294/eeaj.v8i2.31500.

Subarkah, A. \& Nurkhin, A. (2018). Pengaruh Status Sosial Ekonomi Orang Tua, Efikasi Diri, dan Bimbingan Karier terhadap Minat Melanjutkan ke Perguruan Tinggi pada Siswa SMA Negeri 1 Kejobong. $\begin{array}{lllll}\text { Economic Education Analysis } & \text { Journal, } & \text { 7(2), }\end{array}$ https://journal.unnes.ac.id/sju/index.php/eeaj/article/view/28247.

Sudjarwo, R., Wahyudin, A., \& Sudarma, K. (2019). The Role of Self-Efficacy in Mediating the Effect of Entrepreneurial's Knowledge, Personality and Family Circles Against the Enterprise's Interest. Journal of Economic Education, 8(1), 67-74. https://journal.unnes.ac.id/sju/index.php/jeec/article/view/31612.

Sugiyono. (2019). Metode Penelitian Kuantitatif, Kualitatif dan R\&D. Bandung: Alfabeta.

Sujarweni, V. W. (2014). SPSS untuk Penelitian. Yogyakarta: Pustaka Baru Press.

Sunyoto, D. (2013). Analisis Regresi dan Uji Hipotesis. Jakarta: PT Buku Kita.

Umma, I. \& Margunani. (2015). Pengaruh Motivasi Belajar, Prestasi Belajar, dan Kondisi Ekonomi Keluarga terhadap Minat Siswa Melanjutkan Pendidikan ke Perguruan Tinggi Kelas XI IPS di SMA Negeri Sekecamatan Ngaliyan Semarang. Economic Education Analysis Journal, 4(1), 242-249. https://journal.unnes.ac.id/sju/index.php/eeaj/article/view/4702. 
1848 Pengaruh Self Efficacy terhadap Minat Melanjutkan Studi S2 pada Mahasiswa Prodi Pendidikan Administrasi Perkantoran-Lailatul Fitria Hanim, Durinda Puspasari

DOI : https://doi.org/10.31004/edukatif.v3i4.682

Undang-undang Republik Indonesia Nomor 12 Tahun 2012 Tentang Pendidikan Tinggi.

Widyani, A. A. D., Sarmawa, I. W. G., \& Dewi, I. G. A. M. (2017). The Roles of Knowledge Sharing in Mediating the Effect of Self-Efficacy and Self-Leadership Toward Innovative Behavior. Jurnal Manajemen dan Kewirausahaan, 19(2), 112-117. https://doi.org/10.9744/jmk.19.2.112-117.

Zimmerman, B. J. (2000). Self-Efficacy: An Essential Motive to Learn. Contemporary Educational Psychology 25, 82-91. https://doi.org/10.1006/ceps.1999.1016. 